\title{
The Church as the new Family of God
}

\author{
Paweł Rabczyński* \\ pawel.rabczynski@uwm.edu.pl \\ https://orcid.org/0000-0002-8732-7019
}

https://doi.org/10.31192/np.19.1.2

UDK / UDC: 27-242:27-72

27-72-144

Pregledni članak / Review

Primljeno / Received: 17. kolovoza 2020. / Aug 17, 2020

Prihvaćeno / Accepted: 14. rujna 2020. / Sep 14, 2020

Jesus founded His Church as the new family of God by instituting the Twelve. The new family is a real space which fulfils the Kingdom of God. It is a community of Jesus' disciples which fosters the rule of God in the world and has an explicitly institutional dimension. The founding of the new family fulfils the promise to create the new Israel made in the Old Testament. The ethos of the new family of God is aimed at proclaiming the universal reign of God, as it is the mission bestowed on the family by Jesus. Its moral principles were laid out in the Sermon on the Mount. The new family of God is a space where all the promises made by God to Israel come to fulfilment. In this sense, we can speak of continuity between the nation of Israel and the Ecclesia. The Church does not replace the people of the Old Testament but is a continuation thereof in Jesus Christ.

Key words: Church, Church and Israel, ethos of the new family of God, new family of God, origin of the new family of God.

\section{Introduction}

One of the oldest questions of theology is the one about the Church. From the very beginning, the disciples of Jesus Christ strived to characterise its genesis and essence (Ignatius of Antioch, the Didache, Hermas, Justin Martyr, Peter's Sermon, the Epistle to Diognetus, Clement of Rome) ${ }^{1}$. The scriptures of

\footnotetext{
* Paweł RABCZYŃSKI, doctor habilitated in theological science, professor of the University of Warmia and Mazury in Olsztyn, Faculty of Theology; Address: ul. Hozjusza 15, 11-041 Olsztyn, Poland.

${ }^{1}$ Cf. John Norman Davidson KELLY, Poczatki doktryny chrześcijańskiej, Warszawa, Instytut Wydawniczy Pax 1988, 146-168; Mariusz TERKA, Teologiczna geneza Kościoła w świetle pism wybranych Ojców Kościoła, in: Wczesne chrześcijaństwo a religie, Ireneusz Sławomir LEDWOŃ, Mariusz SZRAM (ed.), Lublin, Wydawnictwo KUL, 2012, 585-639.
} 
the New Testament refer to the Church as mysterion - a mystery inextricable from the mystery of Christ (Eph. 3, 1-12; 5, 21-32). It is a part of the economy of salvation and thereupon, a part of the divine revelation; the last stage in the history of salvation ${ }^{2}$. The Church is a mystery not in the exclusive sense, as "mysterious teachings" reserved for the chosen few, but as an inclusive reality which weaves transcendental, supernatural elements into the natural course of history. In the mystery of the Ecclesia, history is pervaded with the presence of God and His saving action is embodied in sacramental signs ${ }^{3}$.

Nowadays, we are witnessing a shift from the institutional concept of the Ecclesia and the related emphasis on its external, social, and legal aspects, towards more personalistic interpretations ${ }^{4}$. As a result, the old reistic question about the Church: ("What is the Church?") is replaced by the personalistic "Who is the Church?". One of the legitimate answers to that inquiry is that the Church is a community (family) of divine and human persons (the Holy Trinity and the faithful). This unique communion is both mystic and pneumatic in character, as it is fulfilled in Jesus Christ - true God and true man - through the Holy Spirit ${ }^{5}$.

\section{Human and divine - nature and origins of the Church}

The mysterious character of the Church, as well as its human and divine origins and nature, all point to the complexity of the Ecclesia ${ }^{6}$. Therefore, the diversity and multiplicity of designations of the Church used in the Holy Scriptures and the tradition, with many referring to everyday life or family life, cannot come as a surprise. All the images, comparisons and analogies are semiotic or symbolic and reflect some aspect of the rich ecclesiastical reality? The Church is known under the following names: the sheep (Jn. 10,1-10), the flock (Isa. 40, 11; Ezek. 34, 11-16), God's field (1 Cor. 3, 9), the chosen vineyard (Mt. 21, 33-43; Mk. 12, 1-9; Lk. 20, 9-16; Isa. 5, 1-7), God's building (1 Cor.

${ }^{2}$ Cf. Hugolin LANGKAMMER, Nowy Testament o Kościele, Wrocław, Wydawnictwo św. Antoniego, 1995, 14-16; Salvatore PIÉ-NINOT, Kościót jako ostatni etap historii zbawienia, in: Chrześcijaństwo jutra. Materiały II Międzynorodowego Kongresu Teologii Fundamentalnej, Lublin, 18-21 września 2001, M. Rusecki et al. (ed.), Lublin, Towarzystwo Naukowe KUL, 2001, 403-443.

${ }^{3}$ Cf. Viktor WARNACH, Kościót jako tajemnica, in: Nowy obraz Kościoła po Soborze Watykańskim II, Bernard LAMBERT (ed.), Warszawa, Instytut Wydawniczy Pax, 1968, 26-32.

${ }^{4}$ Cf. Joseph RATZINGER, Pielgrzymujaca wspólnota wiary. Kościót jako komunia, Kraków, Wydawnictwo M, 2003, 135-136.

${ }^{5}$ Cf. Langkammer, Nowy Testament o Kościele..., 15-16; Czesław Stanisław BARTNIK, Kościót, Lublin, Wydawnictwo KUL, 2009, 62-63; Marian RUSECKI, Traktat o Kościele, Krzysztof KAUCHA, Piotr KRÓLIKOWSKI, Jacenty MASTEJ (ed.), Lublin, Wydawnictwo KUL, 2014, 7-12.

${ }^{6}$ Cf. Jean RIGAL, Le Mystère de l'Église, fondements théologiques et perspectives pastorales, Paris, Éd. du Cerf, $1992^{2}$.

${ }^{7}$ Cf. Bartnik, Kościót..., 59-63. 
3, 9), God's household (1 Tim. 3, 15), members of God's household, a dwelling in which God lives by His Spirit (Eph. 2, 19-22), God's dwelling place among the people (Rev. 21, 3), the temple of God (2 Cor. 6, 16), the holy city, the new Jerusalem (Origen, Tertullian), Jerusalem that is above, our mother (Gal. 4, 26; Rev. 12, 17), the Bride of the Lamb (Rev. 19, 17; 21, 2. 9; 22, 17) ${ }^{8}$. The key designations include the Body of Christ (Col. 1, 18; Eph. 1, 22-23; 5, 21-33) ${ }^{9}$, the temple of the Holy Spirit (Eph. 2, 18; 1 Cor. 3, 16; 6, 19) ${ }^{10}$, the people of God (1 Pet. 2, 9-10) ${ }^{11}$, the sacrament ${ }^{12}$, the community - communio (1 Jn.. 1, 3; Acts, 2, 42; Gal. 2, 9-10; 1 Cor. 10, 16-17; Rom. 12, 4-5) ${ }^{13}$.

The images, comparisons, and analogies evoked above offer a better insight into the intrinsic nature of the Church. They all share a clear reference to Jesus Christ, the Founder of the Church. The whole life and activity of the Saviour constituted the foundation of the Ecclesia. Modern theology, as established in the doctrine of the Second Vatican Council, avoids pointing to any single event as the founding of the Church. Instead, it lists the stages of its foundation and presents its genesis as a process of fulfilling the divine economy of salvation.

The Constitution Lumen Gentium sets forth that the eternal Father, in His plan to lead people to salvation, resolved to

${ }^{8}$ Cf. Second Vatican Council, Lumen gentium. Dogmatic Constitution on the Church (21. XI.1964) (LG), 6, in: Second Vatican Council, Konstytucje. Dekrety. Deklaracje, Poznań, Pallottinum, 19863, 107-109.

${ }^{9}$ Cf. LG 7; Langkammer, Nowy Testament o Kościele..., 13-14.

${ }^{10}$ Cf. LG 7; Jürgen MOLTMANN, Kirche in der Kraft des Geistes. Ein Beitrag zur missionarischen Ekklesiologie, Munich, Chr. Kaiser Verlag, 1975.

${ }^{11}$ Cf. LG 9-17; International Theological Commission, Wybrane zagadnienia z eklezjologii (1985) [Select Themes on Ecclesiology (1985)] (STE), in: Od wiary do teologii. Dokumenty Międzynarodowej komisji Teologicznej 1969-1996, Janusz KRÓLIKOWSKI (ed.), Kraków, Wydawnictwo Księży Sercanów, 2000, 204-205, 208-209; Marie-Dominique CHENU, Peuple de Dieu dans le monde, Paris, Éd. du Cerf, 1966; Bartnik, Kościót..., 49-56; Gerhard LOHFINK, Czy Bóg potrzebuje Kościoła? O teologii ludu Bożego, Poznań, W drodze, 2005; Langkammer, Nowy Testament o Kościele..., 11-12.

${ }^{12}$ Cf. LG 1, 48; Second Vatican Council, Gaudium et spes. Pastoral Constitution on the Church in the Modern World (7.XII.1965) (GS), 45, in: Second Vatican Council, Konstytucje. Dekrety. Deklaracje, Poznań, Pallottinum, 1986², 574; STE 225-228; Viktor WARNACH, Kościót jako sakrament, in: Nowy obraz Kościoła po Soborze Watykańskim II, Bernard LAMBERT (ed.), Warszawa, Instytut Wydawniczy Pax, 1968, 32-38; Yves CONGAR, Un peuple messianique. L'Église, sacrement du salut, salut et liberation, Paris, Éd. du Cerf, 1975; Walter KASPER, La théologie et l'église, Paris, Éd. du Cerf, 1990, 343-365.

${ }^{13}$ Cf. LG 7, 11; Congregation for the Doctrine of the Faith, Communionis notio. List do biskupów Kościoła katolickiego o niektórych aspektach Kościoła pojętego jako komunia [Letter to the Bishops of the Catholic Church on some aspects of the Church understood as communion] (28.V.1992), in: W trosce o petnie wiary. Dokumenty Kongregacji Nauki Wiary 1966-1994, Tarnów, Wydawnictwo Diecezji Tarnowskiej Biblos, 1995, 390-401; STE 217-219; Joseph RATZINGER, Schauen auf den Durchbohrte. Versuch einer spirituellen Christologie, Einsiedeln, Johannes-Verlag, 1984, 60-84; Walter KASPER, La théologie et l'église, Paris, Ėd. du Cerf, 1990, 389-410; Jean RIGAL, L'ecclésiologie de communion. Son evolution historique et ses fondements, Paris, Éd. du Cerf, 2000; Ratzinger, Pielgrzymujaca wspólnota wiary..., 116-119; Communio w chrześcijańskiej refleksji o Kościele, Andrzej CZAJA, Marek MARCZEWSKI (ed.), Lublin, Towarzystwo Naukowe KUL, 2004. 
"assemble in the holy Church all those who would believe in Christ. Already from the beginning of the world, the foreshadowing of the Church took place. It was prepared in a remarkable way throughout the history of the people of Israel and by means of the Old Covenant. In the present era of time the Church was constituted and, by the outpouring of the Spirit, was made manifest. At the end of time, it will gloriously achieve completion" ${ }^{14}$.

Continuing that line of thought, the International Theological Commission in the document Select Themes of Ecclesiology enumerates ten fundamental events that led to the foundation of the Ecclesia and simultaneously constitute stages in the process of the founding of the Church. The list includes 1) the promises about the people of God, made in the Old Testament and present in the preaching of Jesus; 2) Jesus' appeal to all the people to convert and believe in him; 3) the institution of the Twelve as a sign of Israel of the end times; 4) the renaming of Simon Peter and his privileged place in the circle of the disciples and his mission; 5) the rejection of Jesus by Israel and the schism between the people of the Old Covenant and the disciples of Jesus; 6 ) institution of the Supper, which anticipates the passion and the death of Jesus and preaches the universal Reign of God; 7) the resurrection of Jesus Christ, which rebuilds His communion with the disciples and initiates them into the ecclesial life; 8) the sending of the Holy Spirit, which makes the Church a truly divine creation; 9) the mission to the Gentiles and the Church of the Gentiles; 10) the definitive break between the Church and the synagogue ${ }^{15}$. This breakdown exposes the trinitary dynamics that ruled the founding of the Church, and thus the whole economy of salvation ${ }^{16}$. A consideration of these phases is indispensable in any attempt at defining the Ecclesia and revealing its ministry.

In the discussion on the designation of the Church, modern ecclesiology readily refers to interpersonal relations and dialogue as an instrument in social encounters; it is keen on the sense of intimacy and security. This approach should not be confused with theological horizontalism, which would divest the Ecclesia of its transcendental divine reality. On the contrary: personal and existential interpretations correspond with the state of the present mentality and as such, they can be helpful in revealing the ecclesiastical perspective of the Church oriented around the history of salvation, as well as the continuous actualisation of the Church throughout the history of man and the world (permanent ecclesiogenesis). Such a view is expressed in the designation of Ecclesia as a family.

The topicality and the importance of presenting the Church as the new family of God are evident from the teaching of the most recent popes, as exempli-

\footnotetext{
${ }^{14}$ Cf. LG 2.

${ }^{15}$ Cf. STE 201-202; Henryk SEWERYNIAK, Święty Kościót powszedni, Warszawa, Biblioteka Więzi, 1996, 27.

${ }^{16}$ Cf. Jerzy PAŁUCKI, Trynitarny wymiar Kościoła. Studium patrystyczne, Lublin, Wydawnictwo KUL, 2007.
} 
fied by the four statements of Pope Benedict XVI and Pope Francis discussed below.

Benedict XVI, in the encyclical letter on Christian love penned in the early days of his pontificate and entitled Deus caritas est, reminds us that the deepest nature of the Ecclesia is expressed in its three-fold responsibility: to proclaim the word of God, to celebrate the sacraments and to exercise the ministry of charity. Thus, the exercise of charity becomes an ecclesial imperative. The Pope emphasises that the Church, construed as the family of God, must make certain that none of its members suffers through being in need, like any natural family would ${ }^{17}$.

Furthermore, Benedict XVI refers to the Ecclesia as the family of God in the context of the trinitarian communion. The family, by modelling its life on the unity of three divine persons, receives and passes on the truths of faith in a spirit of harmony, imparts love to everyone, shares joys and sufferings, learns to seek and to grant forgiveness, makes good use of the different charisms, achieving everything under the leadership of the bishops. The pope summarises that ecclesial communities should be built more and more like families, to reflect the beauty of the Holy Trinity and to evangelise through passing on the living love $^{18}$.

In turn, Pope Francis in one of his catecheses exploring the mystery of the Church has emphasised that the whole history of salvation is the story of God who seeks out human beings with love, invites them to communion, and makes them His family. The acceptance of God's plan of love, which we express through our desire of God, our communion and friendship with Him, and participation in His divine life, is liberating. It helps us emerge from the temptation of individualism and our tendency to close ourselves into ourselves. That acceptance becomes fulfilled to the fullest in God's family - a community He creates Himself. The Bishop of Rome concludes: "The Church is a family in which we love and are loved"19.

Continuing in the same vein and referring to the experience of family ties, Pope Francis invites the young in particular to deepen their sense of belonging to the Church and to participate more actively in its life. Such an attitude gives meaning to human existence: "[it is] worth the effort to have the Church as a mother, as a teacher, as a home, as a family, and, despite human weaknesses and difficulties, capable of radiating and conveying Christ's timeless message; worth the effort to hold onto the boat of the Church which, despite the world's cruel storms, continues to offer shelter and hospitality to everyone; worth the effort to listen to one another; worth the effort to swim against the tide and

\footnotetext{
${ }^{17}$ Cf. BENEDICT XVI, Deus caritas est. Encyclical letter on the Christian love (25.XII.2005), Rome, Libreria Editrice Vaticana, 25.

${ }^{18} \mathrm{Cf}$. BENEDICT XVI, Homily at the mass celebrating the end of the 7th World Meeting of Families (Bresso-Mediolan, 3.VI.2012).

${ }^{19}$ Cf. FRANCIS, The Family of God. Catechesis during the General Audience (Vatican, 29.05.2013).
} 
be bound by lofty values: family, fidelity, love, faith, sacrifice, service, eternal life"20.

The designation of the Church as the family of God is a response to the old postulate of a distinguished theologist and minister, Archbishop Alfons Nossol, who sought to bring theology "closer to life", for only then could it bear fruit and effectively influence the everyday existence of Christians ${ }^{21}$.

\section{Jesus founds the new family of God}

Referring to the Church as the family of God is rooted in the Bible, as already discussed. The profound sense of this designation may be explained through the activity of Jesus Christ.

The ministry of Jesus focused on the proclamation of the Kingdom of God. To fulfil the reign of God in the world (and save it from becoming abstract, vague, and incomprehensible), He called up disciples and from their midst gathered (instituted, created) the Twelve (Mk. 3, 14-15), which were named apostles after the Passover ${ }^{22}$. They represent the twelve tribes of Israel, the seed of the new people of God, the beginning of a restored Israel of the end times - the Church. The Twelve provide the foundation and the first manifestation of the Ecclesia. This new congregation of the people of God is a revelation and concretisation of the promised Kingdom of God. The Church is the community which creates space for the reign and the effective action of $\operatorname{God}^{23}$.

By the will of Jesus, His disciples become the new family of God. They follow the Master upon His call, leaving their natural families and property to start a new life oriented around the Kingdom of God (Mk. 10, 29-30). They need to disconnect from their close ones both externally and internally, to break family ties in order to become free persons, at liberty to "follow Jesus", i.e. to become His disciples (Mk. 1, 16-20). By relinquishing their way of living, they start a new existence based on a personal relationship with the Master and accept their new responsibilities and duties. The calling of the disciples as discussed by Jesus in His discourse on the necessity to break family ties (Lk. 14, 26), carrying the cross $(\mathrm{Lk} .14,27)$, and the prize for those who follow Him unconditionally (Mk. 10, 29-30; Mt. 10, 37-42), the precedence of the calling over natural obligations (Mt. 8, 21-22) is essentially radical and involves an enmity towards the

\footnotetext{
${ }^{20}$ Cf. FRANCIS, Address at the opening of the Synod of Bishops on Young People (Vatican, 3.10.2018).

${ }^{21}$ Cf. Alfons NOSSOL, Teologia bliższa życiu, Paris, Éd. du Dialogue, 1993, 11-12.

${ }^{22}$ Cf. Hugolin LANGKAMMER, Wprowadzenie do Ksiag Nowego Testamentu, Wrocław, Wydawnictwo Wrocławskiej Księgarni Archidiecezjalnej, 1992, 70-79.

${ }^{23}$ Cf. Lohfink, Czy Bóg potrzebuje Kościoła?..., 202-204, 206-207; Langkammer, Wprowadzenie do Ksiag Nowego Testamentu..., 81-84, 389-392; Joachim GNILKA, Jezus z Nazaretu, Kraków, Wydawnictwo M, 2005, 245-252.
} 
family (Mt. 10, 34-36; Lk. 12, 51-53). This radicality serves to emphasise that Jesus and His work take absolute precedence in the life of the called ${ }^{24}$.

The disciples are "a little flock" whereupon God has been pleased to bestow His Kingdom (Lk. 12, 32). The new family of God is a community of Jesus' disciples which fosters the rule of God in the world. There are no masters and servants, the ruling and the ruled. All people are disciples of Jesus, i.e. loving brothers and sisters ${ }^{25}$. They forfeit their "homes and fields" but only on the surface. Their treasure - their share in the "promised land" proclaimed in the Old Testament and in the blessings of the Messianic Age - is not their adherence to Israel, but to the new family of $\mathrm{God}^{26}$. By renouncing everything for the Kingdom of God, the new family of God forgoes the pagan fear for life together with all the safeguards in favour of the full trust in the Divine Providence. Voluntary acceptance of poverty is the start on their way of the imitation of Christ. The new family of God is a community of the poor ${ }^{27}$.

Jesus bestowed upon the new family of God an organisational framework and a social order (a distinct system). Those who see the Ecclesia as an indefinite group of charismatics gathering around their Master are mistaken. The new family of God unites the charismatic (spiritual) dimension with an institutional structure. We cannot forget that the new family of God has been founded to fulfil the promise to create the new Israel made in the Old Testament (Isa. 41, 20; 43, 1. 19). The new people of God of the end times is not born in a vacuum. It emerges as a definite structure from the existing social order of Israel. The Twelve represent the new people of God of the eschaton; they are the pillars of the Church. Their calling and their unique nomination by Jesus may be regarded as the foundation of the future ecclesiastical office, which fosters the faith of the new family of God in the true apostolic doctrine (the continuity of the apostolic succession $)^{28}$.

The institutional character of the new family of God is further revealed in its responsibilities. Jesus entrusts the new family with responsibilities that are characteristically stable and unchanging. The disciples shall accompany the Master, preach the gospel, and chase away evil spirits (Mk. 3, 14-15). Being with Christ and gathering around Him without ceasing is a sign and a symbol of the union between the new people and God, the union of the new family of God. The proclamation of the good news on salvation, together with exorcisms, is the imitation of Jesus, the prolongation of His words and acts (Mk. 6, 6-13). The new family of God acts on behalf of Christ, with Christ, and even in His

\footnotetext{
${ }^{24}$ Cf. Langkammer, Nowy Testament o Kościele..., 36-38; Karol Herman SCHELKLE, Teologia Nowego Testamentu, Vol. 3: Etos, Kraków, Wydawnictwo WAM, 1984, 233-235.

${ }^{25}$ Cf. Gnilka, Jezus z Nazaretu..., 318.

${ }^{26}$ Cf. Lohfink, Czy Bóg potrzebuje Kościoła?..., 204-205.

${ }^{27}$ Cf. Schelkle, Teologia Nowego Testamentu..., 290-295.

${ }^{28}$ Cf. Lohfink, Czy Bóg potrzebuje Kościoła?..., 242-243, 247-248; Langkammer, Wprowadzenie do Ksiag Nowego Testamentu..., 79-81.
} 
stead. It remains united with its Founder, as illustrated by Paul's metaphor of the Head and the Body (Col. 1, 18; Eph. 1, 22-23; 5, 21-33). Jesus makes His family the official witnesses of the new saving reality. Through the Church, understood as the new family of God, the Saviour and His epiphanic and saving action in signs become present ${ }^{29}$.

\section{The ethos of the new family of God}

When Jesus Christ founded the new family of God, He instituted a new existence of man in the individual and the social dimension alike. The ethos of the new family of God follows from the new existence in Christ and His Spirit. Faith in Jesus requires the disciple to adopt a particular ethos. The conduct of the disciple may be encapsulated in the broad concept of the imitation of Jesus and living in the Holy Spirit, which is a rather radical form of subjecting everything to the imperative of proclaiming the Kingdom of God (Lk. 9, 60).

The advice given by Jesus and His requirements for the new family of God may be tallied as the morality of obedience. The new ethos of the members of the Church is evident from their new perspective on salvation, adopted in the light of the coming reign of God. The new perspective gives rise to Christ's demand to uphold a certain morality and to a new understanding of obedience to God. The morality of the Ecclesia is determined by the Kingdom of God which, though already present in Jesus and His new family (Lk. 17, 21), is a part of the eschatological future. Every member of the Church is always "already there" and "not yet there". The Kingdom of God defines his present and future, which throws him into a state of alert anticipation, or even a constant readiness to the eschatological fulfilment in Christ. The whole ethos of the new family of God is defined in relation to the coming universal reign of God. In that perspective, all else becomes immaterial. That is the reason for the required dissolution of family ties, renouncement of home, property, or even denial of oneself (Lk. 14, 26-27; Mk. 9, 43-48; Mt. 19, 12; Lk. 12, 16-20). The participation of the Ecclesia in the Kingdom of God takes precedence (Mt. 6, 33) ${ }^{30}$.

Jesus presented His detailed instructions for the members of His new family in the Sermon on the Mount (Mt. 5-7), which may be dubbed the programme of the Kingdom of God. Jesus speaks therein against legalism, which reduces the relationship between man and God to a legal relationship. Israel legitimised itself with strict compliance with laws and regulations. Arduous fulfilment of the Law with a focus only on its letter, rather than its spirit, contorted the meaning of the commandments and obscured the true image of God. The Mas-

\footnotetext{
${ }^{29}$ Cf. Lohfink, Czy Bóg potrzebuje Kościoła?..., 249-251.

${ }^{30}$ Cf. K. H. Schelkle, Teologia Nowego Testamentu..., 19-20; Gnilka, Jezus z Nazaretu..., 222-228; Langkammer, Wprowadzenie do Ksiag Nowego Testamentu..., 67-70.
} 
ter exposed casuistry as a grave abuse, which sparked a violent reaction from the contemporary religious elite. In the Sermon on the Mount, Jesus preaches clearly that God does not oblige men to follow the letter of the Law, but to understand its sense as the way to salvation. That sense will never be discovered without a focus on the commandment of love. The source of the Law as understood in this framework is the universal saving will of God (1 Tim. 2, 4; 4, 10; Jn. 1, 29) and His love for the people (Jn. 3, 16-18) ${ }^{31}$.

By proclaiming the new image of God as the loving father, Jesus introduces a new morality ${ }^{32}$. The ethos of the new family of God involves almost childlike obedience to God in Heaven. The Church places herself in the hands of God entirely, like a child who does not invoke its own merits and the right to salvation but rather accepts God's invitation and His gift. The Church sees the commandments as the word and the will of the Father who wishes His children all the best. The Ecclesia abides by the Law not out of fear or under constraint, but in full trust and love for the Creator and the Saviour. The new family of God avoids all that is not consistent with the will of God and strives for goodness in an effort to be like the Father (Mt. 5, 48). Through these actions, the family legitimises its unique connection with God, a perfectly familial relationship between Father and child ${ }^{33}$.

The new family of God models its conduct on Jesus Himself. It is from Him that it learns how to be with the Father. It strives to attain the Kingdom of God by imitating Christ, living in communion with Him, and continuing His mission. To follow the Master and to be with Him is to fulfil the will of God, to adopt the Christian way of life, and to follow in His footsteps in the service of others, up to the Cross (Mk. 8, 34; Jn. 13, 15), practising the commandment of love (Jn. 13, 34; 14, 23). The love of God and the love of your neighbour amount to the sum of the morality passed on to the disciples by the Master, the encapsulation of all the commandments. It is the principle and the final criterion of the imitation of Jesus ${ }^{34}$.

The new family of God is capable of imitating Jesus through the incessant action of the Holy Spirit. Only those reborn of water and Spirit can enter the Kingdom of God (Jn. 3, 6). The Spirit instructs the Ecclesia, protects it, and helps it proclaim the good news on salvation (Jn. 14, 26; 15, 26; 16, 5-10). Its very existence is the fulfilment of the responsibility borne by the Church, as the word and the power of its members (Mt. 10, 19-20). In the new family of God, the Holy Spirit stands for the ability to give testimony on Jesus, for strength

\footnotetext{
${ }^{31}$ Cf. Schelkle, Teologia Nowego Testamentu..., 15-18; Gnilka, Jezus z Nazaretu..., 279-296; Langkammer, Wprowadzenie do Ksiag Nowego Testamentu..., 386-388.

${ }^{32}$ Cf. Gnilka, Jezus z Nazaretu..., 268-278.

${ }^{33}$ Cf. Schelkle, Teologia Nowego Testamentu..., 18-19.

${ }^{34}$ Cf. Gnilka, Jezus z Nazaretu..., 317-327; Gerhard LOHFINK, Przeciw banalizacji Jezusa, Poznań, Wydawnictwo Święty Wojciech, 2015, 248-254; Franciszek DRĄCZKOWSKI, Mitość synteza chrześcijaństwa, Lublin, Towarzystwo Naukowe KUL, 1991.
} 
and endurance in the face of hardship. The Spirit readies the Ecclesia to fulfil the requirements of the new morality, where the Law and the commandments open people to the saving gift of freedom bestowed on God's children, rather than bringing more sin and damnation ${ }^{35}$.

The ethos of the new family of God is oriented at the proclamation of the Kingdom of God. It rests on the pillars of the imitation of Jesus Christ, the obedience to His word and example, and the life and activity in the Holy Spirit. The Kingdom of God is the present and the future reality, which is why the actions taken by members of the Church must reflect and complement the eschatological situation.

\section{Has the new family of God replaced Israel?}

If Jesus Christ founded the new family of God, one may ask whether it superseded the people of God from the Old Testament. From the times of the Church Fathers (Justin Martyr, Hippolytus of Rome), theology has followed the doctrine called supersessionism, also referred to as replacement theory, which states that Israel was eventually rejected by God as it failed to recognise Jesus as the promised Messiah and Son of God. In the history of salvation, the place of the Synagogue was taken by the Church. Consequently, the promises and obligations of God to Israel are no longer binding, as they were transferred to the new family of God which thus became the true new Israel, the new people chosen by God. It was only at the Second Vatican Council that the theological antagonism related to the replacement theory was partially vanquished. The Council's declaration on the relationship of the Church to non-Christian religions Nostra aetate speaks of the spiritual bond that unites the people of the New and Old Testament. The Ecclesia sees the origins of its faith and calling in the history of the Patriarchs, Moses, and the Prophets. The Church received the revelation of the Old Testament through the people of the Old Covenant. The document emphasises that God still holds the Jewish people dear, as He never regrets His gifts, nor goes back on His promises (Rom. 11, 28-29). In the context hereof, the most important statement is the following: "Although the Church is the new people of God, the Jews should not be presented as rejected or accursed by God, as if this followed from the Holy Scriptures"36. Thus, the status of the Church as the new family of God does not exclude or eliminate the old family of God (Israel). The Ecclesia does not replace Israel but constitutes the fulfilment in Jesus of all the promises made thereto, and although Israel

\footnotetext{
${ }^{35}$ Cf. Schelkle, Teologia Nowego Testamentu..., 20-22.

${ }^{36}$ Second Vatican Council, Nostra aetate. Declaration on the relationship of the Church to nonChristian religions, 4, in: Second Vatican Council, Konstytucje. Dekrety. Deklaracje, Poznań, Pallottinum, $1986^{3}, 337$.
} 
did not attain such fulfilment, it remains the people of $\mathrm{God}^{37}$, the people of the Covenant, which is irrevocable (Num. 23, 19; 2 Tim, 2, 13; Rom. 9, 4; 11, 1-2). The New Covenant in Christ does not revoke the Old Covenant but fulfils it. The New Covenant is grounded in the Old Covenant, which it assumes as true and subject to reinterpretation ${ }^{38}$. The Covenant made by God with Israel has never been revoked ${ }^{39}$. It is still valid by the force of the infallible fidelity of God towards His people ${ }^{40}$.

The validity of the Old Covenant does not imply the existence of two parallel paths to salvation. God wishes to save us all (1 Tim. 2, 3-4), but His universal intermediary is Jesus Christ (Acts 4,12). The final and eternal Covenant in Christ, which gave rise to the new family of God, is the final space of the saving action of God. Intermediation and salvation, also for the Jews, is found only in Jesus (Rom. 1, 16) ${ }^{41}$. The soteriological singularity and universality of Jesus and His Church confirms that there is one way to salvation but does not automatically exclude the Synagogue therefrom. The soteriological reflection of St Paul in the Epistle to the Romans (chapters 9-11) confirms the irrevocable redemption of Israel but does not describe how the people of the Old Covenant will attain salvation without their explicit faith in Jesus Christ. It is the unfathomable mystery of God (Rom. 11, 33) ${ }^{42}$.

As discussed above, the new family of God instituted by Jesus is the seed of Israel of the end times. The Twelve symbolise the people of twelve tribes. The Master, by proclaiming the advent of the universal reign of God in the world, directs its saving message first to the nation of the Old Covenant. It is to Israel that He sends His disciples. Only after He is rejected together with His mission,

${ }^{37} \mathrm{Cf}$. The Commission for Religious Relations with the Jews, The gifts and the calling of God are irrevocable (Rom. 11, 29). A reflection on theological questions pertaining to Catholic-Jewish relations on the occasion of the $50^{\text {th }}$ anniversary of "Nostra Aetate" (no.4) (CRRJ), Vatican, Libreria Editrice Vaticana, 2015, 23.

${ }^{38}$ Cf. CRRJ 27; Joseph RATZINGER, Wielość religii i jedno Przymierze, Poznań, W drodze, 2004, 41-73.

${ }^{39}$ Cf. Katechizm Kościoła Katolickiego, Poznań, Pallottinum, 1994, 121; JOHN PAUL II, Gtębia i bogactwo wspólnego dziedzictwa. Address to representatives of the Jewish community (Mainz, 17.11.1980), 3.

${ }^{40}$ Cf. CRRJ 33; Zbigniew KUBACKI, Kościót, religie i zbawienie. O jedyności i powszechności zbawczej Kościoła oraz zbawczej roli religii niechrześcijańskich, Kraków, Wydawnictwo WAM, 2016, 596-614.

${ }^{41}$ Cf. Second Vatican Council, Dei verbum. Dogmatic Constitution on Divine Revelation, 2, 4, in: Second Vatican Council, Konstytucje. Dekrety. Deklaracje, Poznań, Pallottinum, 1986³, 350351; GS 45; Congregation for the Doctrine of Faith, Dominus Iesus. Declaration on the unicity and salvific universality of Jesus Christ and the Church (6.VIII.2000), Rome, Libreria Editrice Vaticana, 5-8, 13-15; Zbigniew KUBACKI, Jedyność Jezusa Chrystusa. O jedyności i powszechności zbawczej Jezusa Chrystusa w kontekście chrześcijańskiej teologii religii, Warszawa, Wydawnictwo WAM, 2005; Ireneusz Sławomir LEDWON, „... i nie ma $w$ żadnym innym zbawienia". Wyjatkowy charakter chrześcijaństwa w teologii posoborowej, Lublin, Wydawnictwo KUL, 2006, 311-458.

${ }^{42}$ Cf. CRRJ 36; Joachim GNILKA, Teologia Nowego Testamentu, Kraków, Wydawnictwo M, 2002, 156-166; Lohfink, Przeciw banalizacji Jezusa..., 255-257. 
expressed most eloquently in the Paschal Mystery, He orders the apostles to go to the pagans. There is no doubt that the Church is grounded in the history of Israel and its roots trace back to the Old Covenant. Despite the radical novelty of the message proclaimed by the Ecclesia, which focuses on Jesus Christ, Lord and Messiah, Christianity and Judaism evince complementary features as two religions based on the shared faith in one God who plays an active role in the course of history and in His revelatory Word ${ }^{43}$. Therefore, we can speak of the permanent continuity between the nation of Israel and the new family of God.

The teaching of Jesus Christ or His disciples is incomprehensible unless set in the context of the living Jewish tradition. The history of Israel set the stage for the coming of the Master of Nazareth, who sees Himself in the framework of a continuation with His people and its history on one hand, but on the other reveals Himself as the promised Messiah and Son of God, thus surpassing the pursuits of the chosen people. Jesus preaches that the awaited Kingdom of God has come with Him. The end times are upon us. In this sense, we can speak of a rupture in the history of Abraham's descendants and an eschatological break with its continuity ${ }^{44}$.

Israel and the new family of God share the same soil that is Judaism as it was practised the time of Jesus when, after the demolition of the Jerusalem Temple in year 70, it had to relinquish the practice of offerings and gradually limited itself only to prayer and the interpretation of God's revelation. The Hebrew Bible is an integral part of the Holy Scriptures of Judaism and the Church alike, which share its understanding as the word of God, the history of revelation and salvation. The first Christians were Jews who congregated for prayer in a synagogue, respecting the principles of the religion of their fathers and professing faith in Jesus Christ the Messiah, sent by God to save Israel and all the other nations. With time, the faith in Jesus also spread among the pagans and, thus, Christian Antiquity had one Church of Jesus Christ which united Judeo-Christians (Ecclesia ex circumcisione) and pagano-Christians ${ }^{45}$. The final schism between the Church and the synagogue, which transpired in the $3^{\text {rd }}$ or the $4^{\text {th }}$ century under the influence of pagan Christians and in the wake of fierce disputes about the person of Jesus in the bosom of the Jewish community, cemented the identity of the new family of God. Yet, it would be mistaken to think that this schism occurred in opposition to Israel or in a confrontational atmosphere of mutual accusations, which were thrown in abundance throughout history. The Church believes the people of the Old Covenant and its faith to be "the sacred roots of its own Christian identity" ${ }^{\prime 4}$. For too long, members of the Ecclesia considered

\footnotetext{
${ }^{43}$ Cf. FRANCIS, Evangelii Gaudium. Apostolic Exhortation on the Proclamation of the Gospel in Today's World (24.11.2013) (EG), Rome, Libreria Editrice Vaticana, 2013, 247, 249; Gnilka, Teologia Nowego Testamentu..., 104-106.

${ }^{44}$ Cf. CRRJ 14.

${ }^{45}$ Cf. Lohfink, Przeciw banalizacji Jezusa..., 239-241, 245-247, 255-256.

${ }^{46}$ EG 247.
} 
the Jews as accursed by God and blind since they had failed to recognise Jesus as the promised Messiah. Meanwhile, the Jews too often saw Christians as heretics who had strayed from the way of God. Nowadays, Israel and the Church are considered siblings who have grown in different directions - as siblings in any family do - but neither has forfeited God's promises ${ }^{47}$.

$* * *$

The question about the origins and the nature of the Church counts among the oldest questions in theology, yet it remains topical. The Ecclesia, as a reality that is both human and divine, is a mystery inherent to the mystery of Jesus Christ. Nowadays, the institutional concepts of the Church give way to personalistic and trinitary interpretations. One of the legitimate answers to the inquiry about the nature of the Church is that the Church is a community (family) of divine and human persons. This unique communion is both mystic and pneumatic in character, as it is fulfilled in Jesus Christ through the Holy Spirit.

The complexity of the Church is reflected by the multiplicity of its designations known from the New Testament. One of the names borne by the Ecclesia is "the new family of God". This designation, rooted in the Bible, has found its use in the teaching of the recent popes, Benedict XVI and Francis.

By instituting the Twelve, Jesus founded the Church as the new family of God. It is a real space for the revelation and the fulfilment of the Kingdom of God. The new family of God is a community of Jesus's disciples that fosters God's reign in the world. The character of the family is distinctly institutional and its foundation amounts to the fulfilment of the promise to create the new Israel made in the Old Testament. The new family of God acts on behalf of Christ, with Christ, and even in His stead. The Church understood as the new family of God embodies Jesus Christ and His work of revelation and salvation.

The ethos of the new family of God follows from its new existence in Christ and His Spirit. The new morality of the members of the Church is evident from the new perspective on salvation, adopted in the light of the coming reign of God. All else becomes immaterial. To fully participate in the reign of God, the disciples need to relinquish their families, homes, properties and even deny themselves. Detailed instructions for the new family of God were presented by Jesus in the Sermon on the Mount (Mt. 5-7), which may be called the programme of the Kingdom of God. The ethos of Ecclesia members involves the imitation of Jesus Christ and living in the Spirit.

The new family of God is grounded in the history of Israel and its roots trace back to the Old Covenant. The Church is the beginning and the centre of

\footnotetext{
${ }^{47}$ Cf. CRRJ 15.
} 
Israel of the end times, a sign of its eschatic restoration and fulfilment. In this sense, we can speak of the permanent continuity between the nation of Israel and the Ecclesia. The new family of God has not superseded the old one, which is Israel. The emergence of the Church does not invalidate the people of God of the twelve tribes or the Old Covenant. The new family of God is a community in Christ that fulfils all the promises made to Israel which - although it never attained such fulfilment - remains the people of God, the people of the Covenant, which is irrevocable.

The Church is a living community - while preserving its mission and the apostolic structure, it may be construed in various forms and shapes. The designation of the Ecclesia as the new family of God is a response to the postulate to bring theology "closer to life", for only then will it bear fruit and effectively influence the everyday existence of Christians and fulfil its supernatural goal to be the sign and the instrument of salvation in Christ. 


\section{Paweł Rabczyński* \\ Crkva kao nova Božja obitelj \\ Sažetak}

Isus je svoju Crkvu utemeljio kao Božju obitelj osnivanjem zbora Dvanaestorice. Ova nova obitelj je zbiljski prostor u kojem se ostvaruje Božje kraljevstvo. To je zajednica Isusovih učenika koja podupire Božju vladavinu u svijetu te ima izrazito institucionalnu dimenziju. Osnivanje nove obitelji ispunjava starozavjetno obećanje o stvaranju novoga Izraela. Etos ili model ponašanja za novu Božju obitelj jest naviještanje univerzalne Božje vladavine, a to je poslanje koje je Isus povjerio ovoj obitelji. Njezina moralna načela postavljena su u Govoru na gori. Nova Božja obitelj je prostor na kojem se ispunjavaju sva Božja obećanja Izraelu. U tom smislu možemo govoriti o kontinuitetu između Izraela i Crkve (Kahal - Ecclesia). Crkva ne nadomješta starozavjetni narod Božji nego ga nastavlja u Isusu Kristu.

Ključne riječi: Crkva, Crkva i Izrael, etos nove Božje obitelji, nova Božja obitelj, podrijetlo nove Božje obitelji.

(na hrv. prev. Mato Zovkić)

\footnotetext{
* Prof. dr. sc. Paweł Rabczyński, Varmijsko i mazurijsko sveučilište u Olsztynu, Teološki fakultet; ul. Hozjusza 15, 11-041 Olsztyn, Poljska; e-mail: pawel.rabczynski@uwm.edu.pl.
} 